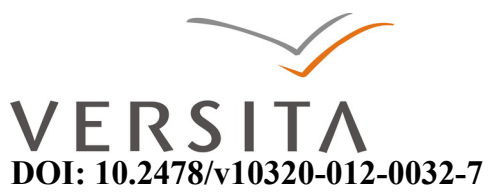

\title{
LADIES AND GENTLEMEN IN RENAISSANCE WESTERN EUROPE EROS VIA THANATOS
}

\author{
ELISABETA ZELINKA
}

West University of Timișoara, 4, Pârvan Blvd, Timișoara, Romania

elisabeta_zelinka@yahoo.com

\begin{abstract}
The present article offers a postmodern (re)interpretation of the $16^{\text {th }}$ century Renaissance set of social etiquettes versus the average citizen's Weltanschauung triggered by his most natural drives and impulses. The epicentral focus of our investigation is the social network(s) built by the different, sometimes oppositional ethical, theological and epistemological codes. What types of motivation triggered certain members of different social layers to observe or to break these codes? Was there any differentiation between clergymen and (fe)male aristocracy? Most importantly, why was the epistemological positionality of men different from that of (educated) women?
\end{abstract}

Keywords:collective consciousness, the French Revolution, "the politics of location", proto-liberation, Weltanschauung

\section{Introduction: Elizabethan phallocratic realities}

William Shakespeare presents the ravishing love story unfolding between the scions of two rival families in Verona: the Montagues and the Capulets. The Bard probably had little idea that the Romeo and Juliet motif would live as long as $21^{\text {st }}$ century cinema and drama, and appear over the signature of world-famous directors and actors: West Side Story, Romeo and Juliet, Shakespeare in Love. This love-related motif can be considered to be more deeply engraved in the collective conscience of the postmodern audience (whether as readers or viewers) than any other. 




The evolution of Romeo and Juliet

\section{The mission of Shakespearean / Renaissance drama}

Firstly, it is important to acknowldge that the postmodern reader probably wonders about the following: why precisely Romeo and Juliet, what does this play have to do with the $16^{\text {th }}$ century Weltanschauung, how can it reflect England, its society with 
its ideas and concepts, when all characters are Italian? After all, not even the setting is in England!

Although two thirds of Shakespeare's plays are set outside the borders of England and two thirds of all his characters are of other nationalities than English (Egyptians, Romans, Spaniards, Italians or Africans), they all symbolize Renaissance England and the $16^{\text {th }}-17^{\text {th }}$ century Shakespearean society. Whether the characters are Roman statesmen or Venetian generals, they are all allegories of the all-round Renaissance persons living in Shakespeare's Elizabethan England (Goethe 1813, available at: http://pages.unibas.ch/shine/shakespundkeinende.html).

It is a fact that one of Shakespeare's favourite locations was indeed Italy and the Italian cities with their fairytale-like Italian sceneries: Mantua, Rome, Venice or in the case of Romeo and Juliet, Verona.

Secondly, Shakespeare offers his readers a quite special imagology as far as Italy is concerned: all that is evil is placed in Italy. This image of Italy is usually a negative one, depicting father-murderers in Rome (Julius Caesar), mean, cruel merchants in Venice (The Merchant of Venice) or a vendetta-ruled society which smothers the innocent love of two young people (Romeo and Juliet).

Therefore, in the present tragedy Verona represents the typical Italian city-state, the most modern type of commercial society available to Shakespeare's historical imagination. Verona is the modern, commercialized, bourgeois society, nevertheless it is driven by a series of deep-rooted social contradictions. Consequently, the epicentral topic of this tragedy might be eros via thanatos, or love through death, as only thanatos has the power to terminate the two dynasties' feuds and to reunite the victimized lovers.

Nevertheless, the play fulfils its social-moralizing mission: according to M. C. Bradbrook (1971:76) Shakespearean drama, like any Renaissance drama, generally had two paramount functions: firstly, to mirror contemporary reality, that is Elizabethan England with all its faults and shortcomings and secondly, to castigate the negative aspects. Romeo and Juliet fulfils its double mission, as an Elizabethan tragedy: The two feuding families indeed come to peace at the end of the play and acknowledge their children as being "Poor sacrifices of our enmity" (V.3.). The horrible acts are revealed and either the villains are punished or they repent. 
Eros, thanatos and hate - the distinctive elements of this triptych co-exist in a perfect symbiosis. At the same time they prove a most useful resource for analysing the $16^{\text {th }}$ century psycho-social realities of England, alongside the socio-political position of the woman during the Elizabethan Renaissance.

\section{Ladies in Renaissance Western Europe}

Women in Renaissance times had a rather pitiful status; to quote Simone de Beauvoir's (1993:xx-xxiii) famous phrase: they indeed were "the second sex". Women were considered weak, inferior to men, both psychologically and biologically. The husband was associated with power, ownership, violence and authority over his wife. Man was superior, thus he became the master of the woman (King 2000:251), while women had absolutely no rights but to get married and give birth to as many children as their health allowed them, hopefully boys and not girls.

In the same line of thought, one should mention Toril Moi, whose theory on women's condition over the past centuries aligns itself with those of the FrenchBulgarian linguist and psychoanalyst Julia Kristeva. Kristeva considers the feminine condition not in terms of essences (as Hélène Cixous does in her Sorties, 1989), but in terms of positionality. Moi and Kristeva (1989:111-112) agree in adopting a positional perspective: 'feminine' is the marginal, "that which is marginalized, by the patriarchal symbolic order". Therefore the 'feminine' "seems to be marginalized (repressed, silenced) by the ruling" (1989:111-112) patriarchal heteronormative canon. Moreover, 'feminine' is all that is pushed to the borderline between man (the norm) and irrational chaos. Thus 'feminine' becomes the symbol of the marginal, of that mysterious principle which is suspended between the masculine norm and unknown chaos.

Does that not automatically position and define the inferior, marginalized and oppressed feminine in opposition to the superior, central and oppressing masculine? The present standpoint of the borderline / of marginality is also shared by bell hooks, but hooks' theory functions as a sequel to Kristeva's and Moi's argumentation. hooks (2004:153-156) calls her theory "the politics of location" and she sees the margin not as a to-be-pitied locus of redemption and repression for women, but as a topos of finding their peace, their peace of mind and of power to gather strength. 
Precisely as hooks (2004:153-156) theorises, not all women of the past wasted all their time on self-pity. It indeed was a Sisyphean task for a young woman to rebel against the absolutism of the Renaissance father figure; nevertheless we witness exceptional cases, such as Juliet and the Nurse. Juliet faces a tough decision: she either accepts her fate imposed by her father (a barren, loveless marriage to Paris) or she uses her marginalized, secondary positionality (that of being a woman) as a topos of finding her peace of mind and her power to act and, if necessary, to react.

Therefore Juliet may be considered as an allegory of the Renaissance protorebellious woman, the antiphallocratic, self-empowered young woman. She fights the central phallocratic norms with all her might and dignity. Women often became subjects of physical and verbal violence, or mere sexual objects, consequently they could be sexually assaulted anytime and anywhere. Women's position during the Renaissance will also be discussed with reference to Juliet's relationship to her father, the absolute phallocratic figure, the pater familias.

\section{Antipatriarchal women in the Renaissance - proto-liberation?}

Concerning the concept of love, love is approached from numerous standpoints. Let us consider Romeo for example, in whose case the idea of love mirrors a clear maturation or evolution. At first, Romeo is in love with a young lady of aristocratic origin, this being the very first stage of the evolution of his eros. In order to suggest that Romeo's first love is shallow and immature, Rosaline is hardly mentioned (and then only in passing) in the opening of the tragedy. In deep contradiction to Juliet, Rosaline only exists in absentia, in Romeo's hot-blooded consciousness. Most importantly, she never enters the stage, unlike Juliet, his true love, who masters the entire play.

Nevertheless, at the beginning of the tragedy, Romeo is unaware of his immature passion for Rosaline. He has not yet passed the maturing trail of falling in love and experiencing true, ardent love (for Juliet). Therefore, Romeo suffers for Rosaline, he is tormented by this feeling, he is shattered, and he feels he cannot live any longer, so powerful is this feeling within his heart. This love towards Rosaline is so boisterous and so burning that it means pain, not happiness. 
Romeo is more in love with the idea of love, with the exaltation of this feeling, than with Rosaline per se. That is why, when he sees Juliet at the ball, where, ironically enough, he only goes to have a chance to meet Rosaline, he immediately forgets her and falls forever in love with Juliet. This will become the true, genuine love of his life, which will lead to his death. Thus his bondage within eros and thanatos.

While in love with Rosaline, Romeo considers this feeling something ephemeral, "a smoke made with the fume of sights", "A madness most discreet" (I.1.). Romeo is so intoxicated by this first, boyish love of his life that he even starts to behave like a melancholic lunatic (melancholy associated with love was a fashionable pose in that period). Benvolio, his friend, even asks him: "Why, Romeo; art thou mad?" (I.2.), while Romeo responds: "Not mad, but bound more than a madman is" (I.2.).

Nevertheless as soon as Juliet appears on the stage, the burning flame for Rosaline is immediately forgotten. Romeo himself acknowledges that he has never experienced true love until that precise moment: "Did my heart love till now? For I ne'er saw true beauty till this night" (I.5.).

Almost the same kind of evolution is to be seen in Juliet's case. She is a tender, fourteen-year-old girl, with a sensitive and noble heart, but totally inexperienced as far as love and marriage are concerned. Juliet sees them as being an honour: "an honour that I dream not of" (I.3.), something in which her power of decision is of no importance, as her father is supposed to arrange her marriage with her suitor, Paris.

At the ball, when Juliet meets Romeo, she instantly falls in love with him. This moment proves decisive for her destiny and becomes a test of maturation and of decisionmaking empowerment. Like Romeo, she too will have to complete a trajectory of maturation, a path of self-empowerment to confront her indomitable pater familias, her mother and her entire social circle, as well as the socio-religious disapprobation of the phallocratic society in which she lives.

It is Juliet's love for Romeo that gives her courage and triggers her maturation process: although barely fourteen, she fully understands the meaning of true love, which may also demand self-sacrifice. That is why she makes the greatest possible sacrifice: suicide out of love for Romeo. Marriage is no longer merely an honour she never dreamt of; it becomes the strongest possible bond and proof of the love she cherishes for Romeo. 
If this proof is impossible to have, she rejects loveless life altogether. For the empowered Juliet, it becomes a matter of 'all or nothing'.

Juliet's process of (somewhat forced) maturation is even more evident if we consider the avalanche of dramatic turns she experiences during the short, four-day plot: Juliet is abruptly hurled into painful adulthood, she has to shoulder the responsibilities of life, love, passion and death, she is courted by a potential husband (Count Paris), falls in love with another (Romeo), secretly marries Romeo, experiences the death of her cousin Tybalt, has one brief passionate night with her new husband, then Romeo is forced to leave the city, she is threatened by her father and nearly disowned, spends almost two days intoxicated to near-death by the potion, is widowed and ultimately commits suicide alongside the body of her dead husband. Tragically, all these painful experiences prove futile, as both Juliet and Romeo have to die: Fate works against them.

Fate is cruel to the two lovers, their love is free of pain only for a few moments, in its primary phase at the ball, while Romeo is still masked and before they learn each other's names. As long as they are unaware of the other's identity, as long as the power of their masks hides their feuding lineages, they are free of any constraint forced upon them by their vendetta-blinded families: "Is she a Capulet? / O dear account! My life is my foe's debt" (I.5.), Romeo exclaims in despair when he learns that his love is in fact a Capulet.

Other such characters in world literature who first have to complete certain steps of maturation before they prove ripe enough to love and to cherish their love are: Natasha Rostova in her love for Pierre in Lev Tolstoy's War and Peace (1869), Clarissa Dalloway in Virginia Woolf's Mrs. Dalloway (1925), Mrs. Dalloway, Louis and Richard in Michael Cunningham's The Hours (1998) and Mr. Rochester in his affection for Jane in Charlotte Brontë's Jane Eyre (1847).

\section{Epicentral phallocracy}

In Lord Capulet the Elizabethan drama unmasks a prominent and intricate character: Juliet's father, Capulet. $\mathrm{He}$ is the typical mighty father-figure of the Renaissance epoch, representing the clear product of the patriarchal world in which everything is governed only by men: he and only he may arrange Juliet's marriage to 
Paris, he organises the ball where the two are intended to meet and he roars at his daughter for not accepting this self-mutilating marriage. Juliet, the real subject of the entire arrangement, has absolutely no right to voice her opinion: she must merely witness other men directing (mutilating) her life and her destiny. Lord Capulet is the epitome of the Renaissance Man, the indomitable, omnipotent father figure and husband figure, who cannot and will not tolerate disobedience.

Capulet has no idea about what true love means. He shares the typical Renaissance outlook on marriage: a woman's social duty and right, the only one besides giving birth to children and a means of transferring wealth from one family to the other (King 2000:248). In Capulet's discussion with Paris about his marriage to Juliet, the bride "is defined as an object of male choice and negotiation" (Ryan 1995:79), while Capulet proves that he knows nothing about his daughter's psychological and emotional potential:

My child is yet a stranger in the world / She hath not seen the change of fourteen years: /

Let two more summers wither in their pride / Ere we may think her ripe to be a bride (I.2.).

There is a generation gap between father and daughter as far as love and marriage are concerned, because Juliet is in fact very "ripe": that same night she meets Romeo, falls in love with him and marries him.

\section{Key characters: the Nurse, anti-patriarchal and subversive}

The Nurse is not a leading character in the present tragedy, yet she plays an indispensable key role in the build-up of the dramatic climax. In Shakespeare's plays, it is often the minor characters who carry just as important messages as the leading characters: a similar example of a supporting character would be the archetypal Fool.

The Nurse is the messenger, she facilitates the dangerous and clandestine wedding, yet later when Romeo is banished (from Verona to Mantua) and the Nurse's love and understanding for Juliet are really tested, it becomes clear that Juliet has grown into a womanly maturity far beyond the Nurse's comprehension. All she can suggest is deceit, of the most callous kind, springing from brutish opportunism and immorality. What she actually suggests is nothing less than bigamy: since marriage means nothing to 
the Nurse but sexual pleasure and Romeo is banned from Verona, Juliet should see no "use" of him. That is why she advises Juliet to quickly forget Romeo and seek pleasure with another man, with Paris: "Your first (husband) is dead - or't were as good he were / As living here and you no use of him" (III.5.).

From a postmodern standpoint, the sexual liberty the Nurse here stands for may be interpreted as women's most dangerous (sexual) rebellion site against Renaissance phallocracy. The Nurse, simple but kind as she is, may be considered a proto-liberated woman, an embryo form of the truly liberated women of the late $19^{\text {th }}$ and $20^{\text {th }}$ centuries. Nevertheless, although she is placed in the $16^{\text {th }}$ century, it is beyond doubt that she is a woman who dares speak up against abusive male authority. We can detect another such 'liberated' woman in the Shakespearean canon: Emilia, Desdemona's lady-in-waiting in Othello.

In IV.3. Emilia bursts out against men, accusing them of arrogance, violence and unfaithfulness to their wives. This can of course be pardoned, as they are men, but the same sins will not be forgiven to women. She dares state that women are physically and psychologically equal to their husbands and that men force women to "fall", that is to cheat on them, by being aggressive and abusive:

But I do think it is their husbands' faults / if wives do fall [...] let them use us well: else let them know, / The ills we do, their ills instruct us so (Othello, IV.3).

\section{Friar Lawrence: the anti-patriarchal clergyman}

Friar Lawrence's position is an extremely special one not only in British literature, but in the entire Western canon. Together with Prince Escalus, he stands in the nexus of this vendetta-governed society, representing faith, justice, order and above all, peace and reconciliation. Nevertheless they prove unable to heal the breach between the two feuding dynasties and thus to overcome the tragic predicament of their offspring.

Except for Romeo and Juliet, Father Lawrence is the only character to understand the depth of true, lasting love. This is the reason why he even scolds Romeo for his flame-like love for Rosaline: "Is Rosaline that thou didst love so dear, / So soon forsaken? Young men's love then lies / Not truly in their hearts but in their eyes" (II.2.). 
Paradoxically, the Franciscan brother is the single character in the play who comprehends love and marriage as a means of reconciliation between the two rival families: "For this alliance may so happy prove / To turn your households' rancour to pure love" (II.3.). He proves the wisest of all the characters, wiser than Lord Capulet or Lord Montague themselves. This is even more noteworthy in Friar Lawrence's case, as he is a member of the clergy, who has little or no tangentiality to erotic love and to eroticism. His educational formation could just as well have made him a thoroughly conservative Catholic priest who would definitely reject a secret marriage ceremony.

Nevertheless, as a Christian who preaches in the name of unconditional love and forgiveness through love, he proves wiser by far than his patriarchal milieu that brutally imposes all of its demands upon the younger generation. He takes enormous risks when he secretly marries the young couple, and what is more, he demonstrate outstanding wisdom in every piece of advice he offers them.

\section{Fate and Time - a demonic pair of Shakespearean characters}

An omnipresent and omnipotent character in Romeo and Juliet is Fate. Nowhere else was Shakespeare so deep a fatalist as in this particular play: the prevailing idea in this drama is that the human being is merely a pawn, a toy in the hands of inexorable Fate, completely exposed to Fate's whimsical moods and mercy.

Moreover, Fate is not conveyed as a positive character but clearly as a negative one: it is a destructive force incessantly working against man and man can do nothing but helplessly witness himself being devoured. The same Weltanschauung is present in King Lear, Hamlet and especially in Macbeth, where Fate is directly represented by the three witches who shape human destinies.

Further masterpieces of world culture where Fate devours the human being are Thomas Hardy's Tess of the d'Urbervilles and Jude the Obscure, Lev Tolstoy's Anna Karenina, Samuel Beckett's Endgame, Hermann Hesse's Siddharta and Das Glasperlenspiel (The Glass Bead Game), Greek tragedies such as Sophocles' Oedipus Rex, the orchestral work Romeo and Juliet composed by Tchaikovsky, and Verdi's opera La Forza del Destino (The Force of Destiny) (Zelinka 2010:157). 
Fate seems to be incessantly working against the human being. Everything happens a little bit too early or too late: in the tomb scene, Romeo thinks Juliet is dead and immediately poisons himself, just a few seconds before Juliet awakes and discloses the truth; Friar Lawrence arrives a few seconds too late to stop Romeo from slaying himself and thus prevent the tragedy. Finally, when Friar John goes to Mantua (where Romeo is banished) to bring him the good news that Juliet is not in fact dead, only asleep, he is not allowed to enter the city - the guards happen to believe he might come from an area affected by the plague. Each of the dramatic disruptions in the play occurs because the course of actions was either delayed or advanced by a few seconds, enough though to trigger the catastrophes.

Fate and Time seem to have joined forces in order to destroy the characters and to bring the play to a tragic end:

\footnotetext{
Shakespeare's great tragic protagonists are indeed 'fools of Time' (Sonnet 124), but in the sense that they are hoodwinked by history. They are overpowered by the prevailing tides of their moment [...] figures born before their time, citizens of an anticipated age whose values their suffering discloses (Ryan 1995:75).
}

Their love is too emancipated for the prison-like society they live in, they share too democratic views concerning their rights as scions of two powerful, rival families, and thus their Fate will crush them: "Romeo and Juliet lays siege to the legitimacy of a world which deprives men and women of boundless love" (Ryan 1995:86). They can do nothing against these superior powers devouring them, as everything is steered by ruthless Fate.

As Father Lawrence so nicely puts it: "A greater power than we can contradict / Hath thwarted our interests" (V.3.). Juliet, Romeo and Friar Lawrence are indeed complex Renaissance characters, yet they are born ahead of their time, in a milieu that is still governed by certain medieval Weltanschauungs.

\section{Conclusion}

These three characters nevertheless fulfil a paramount role, precisely through their Thanatotic dénouement: they carry the true message of the high Renaissance, of the 
Enlightenment and of Romanticism, brought to political fruition by the French Revolution: freedom of spirit, mind and body, that is, "Liberté, égalité, fraternité!".

\section{References}

de Beauvoir, S. 1993 (1949). The Second Sex. vol.1. London: Everyman's Library.

Bradbrook, M.C. 1994 (1935). Themes and Conventions of Elizabethan Tragedy (History of Elizabethan Drama). Cambridge: Cambridge University Press.

Cixous, H. 1989. 'Sorties: Out and Out: Attacks/Ways Out/Forays' in C. Belsey and J. Moore (eds.).The Feminist Reader: Essays in Gender and the Politics of Literary Criticism. New York: Blackwell. hooks, b. 2004. 'Choosing the Margin as a Space of Radical Openness' in S. Harding (ed.). The Feminist Standpoint Theory Reader: Intellectual and Political Controversies. New York: Routledge. King, M.L. 2000 (1998). 'Femeia Renaşterii' in E. Garin (ed.). Omul Renaşterii. Iaşi: Polirom.

Kristeva, J. 1989. 'Women's Time' in C. Belsey and J. Moore (eds.). The Feminist Reader: Essays in Gender and the Politics of Literary Criticism. New York: Blackwell.

Moi, T. 1989. 'Feminist, Female, Feminine' in C. Belsey and J. Moore (eds.). The Feminist Reader: Essays in Gender and the Politics of Literary Theory. New York: Blackwell.

Ryan, K. 1995 (1989). Shakespeare. Prentice Hall, Hemel: Hempstead.

Shakespeare, W. 1998. The Complete Works of William Shakespeare. Chatham, Kent: Mackays of Chatham PLC.

Zelinka, E. 2010. A Psycho-Social Analysis of the Occident. Cunningham, 73 Years after Woolf: a Meeting in Androgyny. Timişoara: Excelsior Art.

\section{Webography}

von Goethe, J. W. 1813. Morgenblatt für gebildete Stände. [Online]. Available: http://pages.unibas.ch/shine/shakespundkeinende.html [2011, May 10] 